\title{
PENGARUH REFUGIA TERHADAP INTENSITAS DAN POPULASI HAMA PENGGEREK DAUN (Spodoptera litura HBN) PADA CABAI KERITING (Capsicum annum L)
}

\section{THE INFLUENCE OF REFUGIA ON INTENSITY AND POPULATION OF PUMP LEAF BRUSH (Spodoptera litura HBN) ON CURRIC CHINESE (Capsicum annum L)}

\author{
Baiq Dian Sarani ${ }^{1)}$, Hery Haryanto ${ }^{2)}$, Meidiwarman ${ }^{2)}$
}

1)Alumni Fakultas Pertanian Universitas Mataram; 2)Dosen Fakultas Pertanian Universitas Mataram heriharyanto@gmail.com

\begin{abstract}
ABSTRAK
Penelitian ini bertujuan untuk mengetahui pengaruh refugia terhadap intensitas dan populasi hama penggerek daun (Spodoptera litura Hbn) pada cabai keriting (Capsicum annum L). Metode yang digunakan adalah metode eksperimental dengan melakukan percobaan di lapangan. Penelitian ini dilaksanakan pada bulan Desember 2018 sampai bulan Maret 2019. Rancangan yang digunakan dalam penelitian ini adalah Rancangan Acak Kelompok (RAK) dengan 4 perlakuan yaitu: Control, bunga Matahari, Marigold, dan Zinnia, masingmasing perlakuan diulang sebanyak 3 kali sehingga diperoleh 60 tanaman sampel dalam 12 unit percobaan. Data hasil pengamatan dianalisa dengan analisis sidik ragam dan diuji lanjut dengan Uji Beda Nyata Jujur pada taraf nyata 5\%. Hasil penelitian menunjukkan bahwa penyebab kerusakan daun pada tanaman cabai keriting (Capsicum annum L) disebabkan oleh hama Spodoptera litura Hbn. Hasil uji lanjut menunjukkan, terdapat perbedaan rata-rata persentase kerusakan yang diakibatkan oleh hama Spodoptera litura Hbn pada setiap perlakuan. Rata-rata persentase kerusakan tertinggi yaitu $(4,803 \%)$ terdapat pada perlakuan R0 (Control), sedangkan rata-rata persentase terendah yaitu $(2,16 \%)$ terdapat pada perlakuan R2 (Marigold). Hasil analisis regresi korelasi menunjukkan bahwa intensitas serangan yang disebabkan oleh Spodoptera litura Hbn yaitu $63,3 \%$ disebabkan oleh populasi hama dan sisanya $27,7 \%$ diakibatkan oleh faktor lain.
\end{abstract}

\section{ABSTRACT}

This research aims to know the effect of refugia on the intensity and population of leaf borer pests (Spodoptera litura $\mathrm{Hbn}$ ) on chili (Capsicum annum L.) the method used the experimentalmethod that conduct experiment in the field. This research was conducted in Desember 2018 until March 2019. The design used in this research was Randomized Complete Block Design (RCBD) with 4 treatments, nomely, control, Sunflower, Marigold and Zinnia treatment repeated 3 times to obtain 60 plant samples in 12 experimental units. Observation data were analyzed by analysis of variance and test further with a Honestly Significant Difference tests at a real level of 5\%. The results showed that the cause of leaf damage in the chili plant (Capsicum annum L.) was caused by the Spodoptera litura Hbn pests in each treatment. The highests percentage of domage is $(4,803 \%)$ found in $R 0$ (Control), while the lowest average persentage is $(2,16 \%)$ found in $R 2$ (Marigold) treatment. The result of the correlation regression analysis showed that intensity of the attacks caused by Spodoptera litura Hbn was 63,3\% by population of pests and $27,7 \%$ was caused by other factors.

Kata kunci: Cabai keriting, Refugia, Spodoptera litura Hbn Key words: Chili, Refugia, and Spodoptera litura Hbn 


\section{PENDAHULUAN}

Cabai keriting (Capsicum annum L) merupakan salah satu komoditas sayuran penting yang bernilai ekonomi tinggi di Indonesia. Tanaman cabai dikembangkan baik di dataran rendah maupun dataran tinggi (Syukur, 2013). Buah cabai banyak digunakan oleh masyarakat sebagai rempah dan bumbu masakan. Seiring dengan pertumbuhan penduduk yang pesat dan berkembangnya industri makanan, maka kebutuhan cabai di Indonesia meningkat (Soelaiman dan Ernawati, 2013).

Provinsi Nusa Tenggara Barat (NTB) adalah salah satu wilayah sentra pengembangan komoditas hortikultura, diantaranya yaitu cabai. Prospek usaha komoditas hortikultura khususnya tanaman cabai keriting (Capsicum annum L.) di NTB tahun 2010 mencapai 817 Ha dengan produksi sebesar 5.780 ton, dengan rata-rata produksi sebesar 7,07 ton/ha, tahun 2011 luas lahan tanaman cabai meningkat menjadi 853 Ha dengan produksi mencapai 6.459 ton, dengan rata-rata produksi yaitu sebesar 7,57 ton/ha, kemudian pada tahun 2014 luas lahan tanaman cabai meningkat yaitu sebesar 1.532 Ha dengan produksi mencapai 20.651 ton dengan rata-rata produksi sebesar 13,47 ton/ha (BPS, 2016). Rata-rata produksi per hektar tersebut di atas, produksi tanaman cabai yanag ada di NTB masih tergolong rendah dibandingkan dengan rata-rata produksi nasional yaitu 22 ton/ha.

Rendahnya tingkat produksi cabai disebabkan karena adanya gangguan hama yang menyerang cabai. Keberadaan hama menjadi faktor pembatas terhadap usaha tani produksi cabai keriting setiap tahun, salah satu hama yang seringkali menyerang yaitu hama (Spdoptera litura $\mathrm{Hbn}$ ) yang menyebabkan matinya daun-daun cabai yang disebabkan oleh hama terebut. Hama ulat grayak merusak di musim kemarau dengan cara memakan daun cabai mulai dari bagian tepi hingga bagian atas maupun bawah daun. Serangan hama ini menyebabkan daun-daun berlubang tidak beraturan sehingga menghambat proses fotosintesis dan akibatnya produksi cabai menurun (Suharsono, 2005).

Kerusakan daun sebesar 12,5\% menyebabkan kerugian ekonomi, dan kehilangan hasil akibat organisme pengganggu tanaman ini dapat mencapai 20 sampai $100 \%$. Sampai saat ini upaya pengendalian yang sering digunkan ditingkat petani yaitu pengendalian menggunkan pestisida kimia. Penggunaan pestisida kimia menjadi masalah yang sangat besar terutama pada tanaman hortikultura yang terus menerus menggunakan pestisida kimia, penggunaan yang terus menerus akan menimbulkan dampak negatif bagi tanaman dan lingkungan. Untung (2008) menyatakan penggunaan jenis insektisida yang sama dengan konsentrasi dan frekuensi yang semakin meningkat dapat mempercepat terbentuknya populasi hama yang resisten, terjadi resurjensi populasi hama yang melampaui ambang ekonomi.

Untuk mengatasi masalah tersebut, dalam membuat tanaman hortikultura terutama sayuran yang sehat, dan aman untuk dikonsumsi, mudah di aplikasikan ditingkat petani, maka perlu dicari alternatif dalam melakukan pengendalian hama tanaman. Di antaranya, mencegah dengan cara bercocok tanam seperti pemanfaatan tanaman pinggir atau tanaman perangkap, dapat mendorong stabilitas ekosistem sehingga populasi hama dapat ditekan dan berada dalam kesetimbangannya. Jenis tanaman pinggir yang dipilih harus mempunyai fungsi ganda yaitu, disamping sebagai penghalang masuknya hama ke pertanaman pokok, juga sebagai tanaman refugia yang berfungsi untuk berlindung sementara dan penyedia tepung sari untuk makanan alternatif predator, jika mangsa utama populasinya rendah atau tidak ada dipertanaman pokok (Mahmud, 2006).

Refugia adalah mikrohabitat yang menyediakan tempat berlindung secara spasial atau temporal bagi musuh alami hama, seperti predator dan parasitoid, serta mendukung komponen interaksi biotik pada ekosistem, seperti polinator atau serangga penyerbuk (Keppel et al, 2012). Refugia mempunyai potensi menyokong mekanisme sistem yang meliputi perbaikan ketersediaan makanan alternatif seperti nektar, serbuk sari, dan embun madu, menyediakan tempat berlindung atau iklim mikro yang digunakan serangga predator untuk bertahan melalui pergantian musim atau berlindung dari faktor-faktor ekstremitas lingkungan atau pestisida dan menyediakan habitat untuk inang atau mangsa alternatif (Landis et al, 2000).

Berdasarkan uraian di atas telah dilakukan penelitian tentang pengaruh refugia terhadap intensitas dan populasi hama penggerek daun (Spodoptera litura $\mathrm{Hbn}$ ) pada cabai keriting (Capsicum annum L).

Tujuan penelitian ini adalah untuk mengetahui pengaruh dari tanaman Refugia terhadap populasi dan intensitas serangan hama penggerek daun (Spodoptera litura $\mathrm{Hbn}$ ) pada tanaman cabai keriting (Capsicum annum L.).

Hasil penelitian ini diharapkan dapat berguna sebagai bahan informasi awal bagi petani dalam melakukan pengendalian hama ulat grayak (Spodoptera litura $\mathrm{Hbn}$ ) yaitu menggunakan sistem refugia sebagai perangkap, baik pada tanaman cabai keriting, maupun pada tanaman pangan.

\section{METODE PENELITIAN}

Metode yang digunakan dalam penelitian ini adalah metode eksperimental yang dilakukan di lapangan. Penelitian ini dilaksanakan di dataran rendah yang berlokasi di Rembiga, Kecamatan Selaparang, Kota Mataram, yang dilakukan mulai pada bulan Desember 2018 sampai dengan Maret 2019. Alat yang akan digunakan pada penelitian ini adalah, cangkul, sabit, ajir, botol spesimen, rol meter, tali rapia, papan lebel, tali salaram, kamera dan alat tulis menulis. Bahan-bahan yang digunakan adalah bibit cabai keriting (Capsicum annum), dan tanaman refugia diantaranya, bunga Matahari (Helianthus annus) bunga Marigold (Tagetes erecta), dan bunga Zinnia 
(Zinnia elegans), dan bunga, NPK, mulsa plastik. Rancangan yang digunakan dalam penelitian ini yaitu Rancangan Acak Kelompok (RAK) yang terdiri dari 4 perlakuan dan masing-masing diulang sebanyak 3 kali sehingga diperoleh 60 tanaman sampel dalam 12 unit percobaan. Adapun masing-masing perlakuan tersebut adalah: R0= Tanpa Refugia (Control); R1= Bunga Matahari; R2= Bunga Marigold; R3= Bunga Zinnia

Penentuan titik tanaman sampel yang akan digunakan sebagai obyek penelitan pada setiap bedengan diambil 5 sampel tanaman dari 11 populasi tanaman dengan menggunakan metode sistematik random sampling. Pada sampel pertama diambil secara acak, kemudian sampel berikutnya ditentukan berdasarkan interval 1tanaman. Observasi lokasi dilakukan pada bulan September 2018, di Rembiga, Kecamatan Selaparang, Kota Mataram. Penentuan lokasi berdasarkan tempat penelitian. Ploting area adalah membuat plot/bedengan sebagai obyek pengamatan. Bibit yang akan digunakan dipersiapkan terlebih dahulu. Setiap komoditi masing-masing terdiri dari satu jenis. Variabel pengamatan meliputi intensitas dan populasi serangan pada tanaman cabai keriting (Capsicum annum $\mathrm{L}$ ).

Pengamatan terhadap intensitas serangan (tingkat kerusakan) bersamaan waktunya dengan pengamatan populasi hama ulat grayak yang dilakukan dengan mengamati intensitas serangan umum dari hama ulat grayak pada tiap-tiap tanaman sampel. Pengamatan dilakukan dengan interval waktu pengamatan 7 hari.

Intensitas serangan hama atau intensitas kerusakan pada tiap-tiap tanaman cabai ditentukan dengan rumus intensitas relatif menurut Hanafiah (2010) sebagai berikut:

$$
\mathrm{I}=\frac{\Sigma(\text { nixvi) }}{N x z} X 100 \%
$$

Keterangan : I= Intensitas serangan; ni= Jumlah tanaman atau bagian tanaman dengan skala kerusakan; vi= Nilai skala kerusakan; N= Jumlah tanaman atau bagian tanaman yang diamati; $\mathrm{Z}=$ Nilai skala kerusakan tertinggi yang ditetapkan. Nilai skornya adalah:; $0=$ Jika tidak ada daun tanaman yang terserang; $1=\mathrm{Jika}<25 \%$ daun tanaman yang terserang; $2=$ Jika $>25-50 \%$ daun tanaman yang terserang; $3=$ Jika $>50-75 \%$ daun tanaman yang terserang; $\quad 4=\mathrm{Jika}>75 \%$ daun tanaman yang terserang

Pengamatan populasi hama dilakukan dengan cara teknik sampling dengan sistem perhitungan in situ yaitu menghitung jumlah hama yang menyerang pada tiap tanaman sampel secara langsung. Pengamatan dilakukan dengan interval waktu 7 hari. Pengambilan sampel dilakukan dengan cara rendomize sampling sehingga didapatkan 60 tanaman sampel. Data hasil pengamatan dianalisis menggunakan analisis sidik ragam pada taraf nyata 5\% dan hasil analisis yang berbeda nyata diuji lanjut dengan uji Beda Nyata Jujur (BNJ) pada taraf 5\%.

\section{HASIL DAN PEMBAHASAN}

\section{Populasi Hama Ulat Grayak (Spodoptera litura Hbn)}

Berdasarkan hasil analisis selama 8 kali pengamatan menunjukkan bahwa, perlakuan refugia memberikan pengaruh terhadap perkembangan populasi hama Spodoptera litura Hbn. Semua perlakuan memiliki jumlah populasi hama yang berbeda-beda, hasil pengamatan di lapangan menunjukkan bahwa populasi hama yang paling mendominasi yaitu pada perlakuan R0 (kontrol). Hal ini dipengaruhi oleh beberapa faktor yaitu biotik dan abiotik. Faktor biotik seperti musuh alami berupa predator dan parasitoid, dan faktor abiotik yaitu curah hujan, kelembaban dan suhu.

Populasi hama tertinggi sampai populasi hama terendah secara berurutan yaitu pada perlakuan R0 (Control) dengan rata-rata yaitu 8,66 ekor, R1 (Matahari) dengan rata-rata 3 ekor, R3 (Zinnia) 4 ekor dan R2 (Marigold) 2 ekor per tanaman. Hasil uji lanjut BNJ dengan taraf nyata 5\%, rerata populasi hama ulat grayak (Spodoptera litura $\mathrm{Hbn}$ ) tertinggi pada perlakuan R0 (Control) yaitu 8,66 ekor dan rerata populasi terendah terdapat pada perlakuan R2 (Marigold) yaitu 2 ekor (Tabel 1). Hal ini menunjukkan bahwa pada perlakuan R2 memberikan pengaruh yang signifikan dalam menurunkan populasi hama Spodoptera litura Hbn dibandingkan dengan R0 (Control).

Tabel 1. Hasil Uji Lanjut Populasi Hama Spodoptera litura Hbn

\begin{tabular}{lc}
\hline Perlakuan & $\begin{array}{c}\text { Populasi Hama } \\
\text { Spodoptera litura } \mathrm{Hbn}\end{array}$ \\
\hline R0 & $8,66 \mathrm{a}$ \\
R1 & $3 \mathrm{~b}$ \\
R2 & $2 \mathrm{~b}$ \\
R3 & $4 \mathrm{~b}$ \\
\hline BNJ5\% & 3,22 \\
\hline
\end{tabular}

Keterangan: Angka-angka yang diikuti huruf yang sama pada kolom yang sama tidak berbeda nyata berdasarkan uji BNJ pada taraf 5\% 
Rendahnya populasi hama pada perlakuan R2 diduga karena bersifat atraktan (menarik) hama. Faktor lain yang mendukung terjadinya penurunan perkembangan populasi seranggahama yaitu, faktor lingkungan fisik yaitu, suhu, cahaya,dan kelembaban. Respon serangga terhadap lingkungan fisik ini berbeda sehingga waktu aktifnya pun berbeda, yaitu pagi, siang, sore atau malam hari. Perubahan suhu mempengaruhi dinamika populasi serangga. Dari data suhu dan kelembaban pada penelitian ini suhu mencapai $27,3^{\circ} \mathrm{C}$ dan kelembaban $84,5 \%$, namun kisaran suhu optimal pada stadia larva yaitu $20-21^{\circ} \mathrm{C}$ dan kelembaban $53 \%$. Jumar (2000) melaporkan bahwa suhu lingkungan sangat mempengaruhi suhu tubuh serangga dimana setiap serangga memiliki kisaran suhu tertentu. Menurut Shi et al (2011), suhu mempengaruhi fisiologi, kelimpahan serangga dan dimensi serangga. Hasil penelitian Thomson et al (2010) menyatakan bahwa perubahan suhu dapat mempengaruhi populasi dan distribusi serangga.

Perlakuan (R1), (R2) dan (R3) memiliki pengaruh yang sama dalam menekan populasi hama penggerek pada daun cabai (Capsicum annum L.), sedangkan R0 tidak memiliki pengaruh yang nyata, sehingga dikatakan bahwa R0 berbeda nyata dengan ketiga perlakuan tersebut. Hal ini dikarenakan bahwa tumbuhan berbunga bisa menarik kedatangan serangga (atraktan) menggunakan karakter morfologi dan fisiologinya. Selain itu, warna bunga juga merupakan salah satu daya tarik bagi serangga (Manzel et al, 1988). Selain warna, kandungan nektar dan polen pada bunga juga menjadi daya tarik bagi serangga (Hydak, 1970).

\section{Intensitas Hama Ulat Grayak (Spodoptera litura Hbn)}

Serangan hama pada tanaman cabai keriting (Capsium annum L.) sangat berpengaruh terhadap hasil produksi. Satu ekor hama dapat menyerang beberapa tanaman. Ciri yang ditimbulkan pada daun yaitu munculnya bercak-bercak putih yang menerawang dan ditandai dengan bagian daun yang koyak dan berlubang karena telah dimakan oleh hama Spodoptera litura Hbn dan mengakibatkan fotosintesis menjadi terhambat. Pada pengamatan selama 8 kali, rata-rata intensitas serangan yang paling tinggi yaitu pada perlakuan R0 sebanyak $4,8 \%$, diikuti oleh perlakuan R1 sebanyak 4,07\%, perlakuan R3 sebanyak 3,04\% dan R2 sebanyak 2,16\%.

Intensitas serangan pada setiap perlakuan berbeda-beda. Rerata intensitas yang paling tinggi terlihat pada perlakuan R0 dan yang paling rendah yaitu terlihat pada perlakuan R2. Rondonuwu (2007) menyatakan bahwa besarnya intensitas kerusakan pada suatu tanaman dipengaruhi oleh populasi hama,jika pada suatu tanaman tidak menggunakan tanaman pembatas pinggir atau refugia sebagai pencegah masuknya hama ke pertanaman, maka populasi dan intensitas serangan hama akan terus meningkat hingga melampaui ambang ekonomi. Huffaker and Messenger (1976) menyatakan bahwa beberapa jenis serangga dapat menyebabkan kerusakan yang sangat serius walaupun populasinya dialam sangat sedikit.

Pada perlakuan R2 merupakan perlakuan yang paling sedikit intensitas serangannya yaitu $2,16 \%$. Intensitas serangan yang sedikit ini disebabkan oleh pengaruh refugia yang bisa menekan intensitas serangan hama. Hal ini sesuai dengan pendapat (Altieri et al, 2007) yang menyatakan bahwa marigold mampu mengikat serangga hama, sehingga hama Spodoptera litura Hbn tidak sampai menyerang tanaman. Faktor lain juga disebabkan oleh lingkungan yang kurang sesuai bagi kelangsungan hidup hama, hal ini akan mempengaruhi perilaku hama khususnya dalam mencari makanan. Hal ini didukung oleh hasil penelitian Hoiss et al (2012) yang menyatakan bahwa jumlah spesies serangga menurun dengan meningkatnya lintang atau ketinggian tempat yang disebabkan oleh pengaruh lingkungan.

Tabel 2. Hasil uji lanjut intensitas serangan Spodoptera litura Hbn

\begin{tabular}{lc}
\hline Perlakuan & $\begin{array}{c}\text { Intensitas serangan } \\
\text { Spodoptera litura } \mathrm{Hbn}\end{array}$ \\
\hline R0 & $4,803 \mathrm{a}$ \\
R1 & $4,07 \mathrm{ab}$ \\
R3 & $3,043 \mathrm{bc}$ \\
R2 & $2,16 \mathrm{c}$ \\
\hline BNJ 5\% & 1,17 \\
\hline
\end{tabular}

Keterangan : Angka-angka yang diikuti oleh huruf yang sama tidak berbeda nyata, R1=Matahari, R2= Marigold, R3= Zinnia, R0= Kontrol

Dari hasil uji lanjut BNJ dengan taraf nyata 5\%, perlakuan R0 (Control) tidak berbeda nyata dengan perlakuan R1 namun berbeda nyata dengan R3 dan R2, hal ini dikarenakan pada perlakuan R0 (Control) tidak ada pengaruh atau tidak diberikan perlakuan atau tanpa refugia, sehingga R0 tidak berpengaruh nyata dalam menekan intensitas serangga hama yang menyerang tanaman cabai keriting (Tabel 2). Hal ini didukung oleh pendapat Rukmana (1997), bahwa tanaman utama akan menjadi sumber makanan dan tempat tinggal organisme-organisme hidup, jika tanaman dalam satu areal tidak menggunakan tanaman pembatas pinggir, maka populasi dan intensitas hama akan terus meningkat. Selanjutnya pada perlakuan R1 tidak berbeda nyata dengan R0 dan R3, namun berbeda nyata dengan R2. Hal ini diduga karena pada perlakuan R1 ini kurang efektif dalam menekan intensitas serangan hama, dikarenakan R1 ini memiliki ukuran tanaman yang sangat tinggi, sehingga hama maupun musuh 
alami sulit untuk menjangkaunya, berbeda dengan R2 (Marigold) bunga ini selain memiliki umur tanam yang panjang, tetapi juga mampu memikat serangga dengan ciri fisiologisnya, diantaranya yaitu baunya yang khas. Hal ini sesuai dengan pendapat Alteri et al, (2007) yang menyatakan bahwa kebanyakan dari serangga lebih menyukai bunga yang berukuran kecil, cenderung terbuka, dengan waktu berbunga yang cukup lama yang biasanya terdapat pada bunga dari famili Compositae dan Ateraceae.

Perlakuan R3 tidak berbeda nyata dengan R1 dan R2 namun berbeda nyata dengan R0 (Control), diduga karena R3 dengan R1 dan R2 memiliki famili yang sama tetapi tingkat kesukaan hama yang berbeda, baik dari warna bunga yang mencolok serta ukuran dari bunga (Altieri et al, 2007). Perlakuan R2 tidak berbeda nyata dengan R3 namun berbeda nyata dengan R1 dan R0. Pada perlakuan R2 (Marigold) menunjukkan intensitas serangan hama ulat grayak (Spodoptera litura Hbn) terendah dibandingkan dengan perlakuan R0, R1, dan R3, Artinya bahwa R2, mampu memberikan pengaruh yang signifikan terhadap intensitas serangan dibandingkan dengan perlakuan R0, R1 dan R3. Diduga karena marigold ini memiliki potensi untuk mampu mengikat serangga hama, sehingga hama Spodoptera litura Hbn ini tidak menyerang tanaman. Hal ini sesuai dengan pernyataan (Altieri et al, 2007) yang menyatakan bahwa tumbuhan berbunga menarik kedatangan serangga menggunakan karakter morfologi dan fisiologi dari bunga, yaitu ukuran, bentuk, warna, keharuman, periode bunga, serta kandungan nektar dan pollen.

Hubungan Antara Intensitas dan Populasi Serangan Hama Ulat Grayak pada Tanaman Cabai

Untuk menguji hubungan antara populasi ulat grayak $(X)$ dengan intensitas serangan ulat grayak $(Y)$ maka dilakukan analisis regresi. Dari hasil analisis menunjukkan persamaan garis regresi $\mathrm{Y}=0,312 \mathrm{x}+2,136$ berdasarkan nilai koefisien korelasi $(0,633)$ dapat dilihat pada Gambar 1

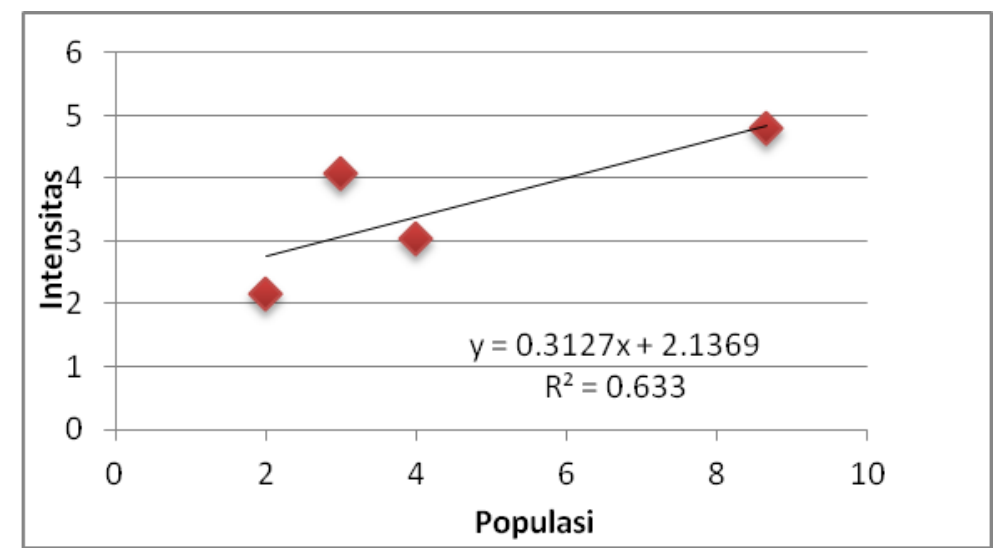

Gambar 1. Hubungan Intensitas dan Populasi Serangan Hama Ulat Grayak (Spodoptera lituraHbn) pada Cabai Keriting

Gambar 1 tersebut di atas, terlihat bahwa koefisien regresinya $\left(\mathrm{R}^{2}=0,633\right)$, bahwa intensitas serangan yang disebabkan oleh Spodoptera litura Hbn yaitu 63,3\% disebabkan oleh populasi hama Ulat grayak (Spodoptera litura $\mathrm{Hbn}$ ), sisanya yaitu 26,7\% disebabkan oleh hama lain, seperti hama Thrips, hama tungau merah dan tungau kuning, hama kutu daun persik, hama kutu kebul, dan hama lalat buah.

\section{KESIMPULAN}

Berdasarkan hasil dan pembahasan yang telah dilakukan dapat disimpulkan bahwa Perlakuan Refugia berpengaruh terhadap intensitas dan populasi hama ulat grayak (Spodoptera litura Hbn). Perlakuan R2 (marigold) dalam menurunkan intensitas dan populasi hama ulat grayak (Spodoptera litura Hbn).

\section{DAFTAR PUSTAKA}

Altieri M.A., Ponti L., dan Nichols C.I. 2007. Mengendalikan Hama dengan Difersifikasi Tanaman. Hlm. 10-11. http://www.salamleisa info., diakses 15 Juni 2019.

Badan Pusat Statistik. 2016. Nusa Tenggara Barat dalam Angka Tahun 2016. BPS Mataram.

Haydak M.H. 1970. Honeybee Nutrition. Annual Review of Entomologi.

Jumar. 2000. Entomologi Pertanian. PT Rineka Cipta. Jakarta.

Keppel G., Van Niel K.P., Wardell-Jhonson G.W., Yates C.J., Byrne M., Mucina L., Schut A.G.T., Hopper S.D., Franklin S.E. 2012. Refugia Identifying and Understanding Safe Havens for Biodiversiti Under Climate Change. Global Ecology and Biogeography 21 (4).393-404. 
Landis D.A., Wratten S.D., Gurr G.M. 2000. Habitat Management to Conserve Natural Enemies of Artrophod Pests in Agriculture. Annu. Rev. Entomol. 45:175-201.

Hanafiah K.A. 2001. Perancangan Percobaan. Universitas Sriwijaya. Palembang.

Hoiss B., Krauss J., Potts S.G., Roberts S., Dewenter I.S. 2012. Altitude acts as an environmentalfilter on phylogenetic composition, traits and diversity in bee comunities. Proceding of the royal society B. http://dx.doi.org.10. 1098/rspb.2012.1581.

Huffaker C.B dan Messenger P.S. 1976. Theory and Prtacticeof Biological control. Academic Press. Inc, London.

Mahmud T. 2006. Identifikasi Serangga di Sekitar Tumbuhan Kangkungan (Ipomoeas crassicaulis Roob). [skripsi] Universitas Negeri Malang.

Menzel R.E., Steinmann J.D., Souza dan Bakchaus W. 1988. Spectral Sensitivity of Photoreceptors and Colour Vision in the Solitary Bee, Osmia Rufa. Jurnal of Eexperimental Biologi.

Rondonuwu, S.L. 2007. Ekologi Serangga. Bahan Ajar Program Semi-Que. Fakultas Pertanian, Universitas Sam Ratulangi, Manado.

Rukmana R. 1997. Hama Tanaman dan Teknik Pengendalian. Penerbit Kanisius. Jakarta.

Shi P., Zhong L., Sandhu H.S., Ge F., Xu X., Chen W. 2011. Population decrease of Scirpophaga incertulas (walker) (Lepidoptera pyaralidae) under climate warming.

Solaiman V dan Ernawati A. 2013. Pertumbuhan dan perkembangan Cabai Keriting (Capsicum annum L) secara In Vitro pada beberapa Konsentrasi BAP dan IAA. Bul. Agrohorti.

Suharsono. 2005. Preferensi Peneluran Hama Penggerek Polong pada Beberapa Galur Varietas Kedelai. Penelitian Pertanian.

Syukur M., Yunianti R., Dermawan R. 2013. Sukses Panen Cabai. Jakarta (ID): Penebar Swadaya.

Thomson L.J., Macfadyen S., Hoffman A.A. 2010. Predicting the effect of climate change on natural enimies of agricultural pests. Bilogical control.

Untung K. 2008. Menejmen Resistensi Pestisida sebagai Penerapan Pengelolaan Hama Terpadu. Centre for Development Studies Indonesia. http://cdsindonesia. Wordpres.com. Diakses 5 Juli 2019. 